\title{
A Sphere Sovereignty Theory of the State: Looking Back and Looking Forward
}

\author{
Renato Saeger Magalhaes Costa \\ T. C. Beirne School of Law, The University of Queensland, Brisbane, Queensland, Australia
}

\section{Email address:}

r.costa@uq.edu.au

\section{To cite this article:}

Renato Saeger Magalhaes Costa. A Sphere Sovereignty Theory of the State: Looking Back and Looking Forward. International and Public Affairs. Vol. 3, No. 1, 2019, pp. 13-19. doi: 10.11648/j.ipa.20190301.13

Received: June 18, 2019; Accepted: July 10, 2019; Published: August 5, 2019

\begin{abstract}
The conception of the State is constantly challenged. The new disruptions and social, political and economical developments have questioned the existence, meaning and scope of the institutionalized State. While many believe that the State is no longer necessary in a current international law environment, others defend its applicability and relevance. Many theories of the State have risen either as justification for its existence or termination. Sphere sovereignty is a known theory within the Christian tradition. It lacks, however, acknowledgement in a wider context. Although this theory presents a relevant approach to the formation and the meaning of the State, its origins and developments are not widely known. The article proposes the reader to look back in order to understand the roots of sphere sovereignty and its basic tenets to, then, look forward, proposing that some challenges in international law could be faced through the lens of sphere sovereignty.
\end{abstract}

Keywords: Sphere Sovereignty, State, International Law, Political Philosophy, Globalization

\section{Introduction}

Our world is experiencing a disruptive era, where new forms of social, political, economic and legal conviviality are continuously challenging traditional values and conceptions. Novel interpretations of the States and interstates interactions arise every day. Traditional notions, such as that of 'sovereignty', no longer justify or explain the existence of a national State. The theories that explain the formation and meaning of the State seem insufficient in the face of the latest disruptions and trends.

Some of these State theories are widely known and have broad academic recognition. Others, however, do not enjoy the same primary positions among the scholars. Would an investigation on the past, and a projection of the future of such 'unknown' theories ameliorate the current disruptive status of our society, and restore the trust on the institutional integrity of the State?

The answer we would like to propose is 'yes'. Although this study does not explain the details on why or how we affirmatively answer the question, it is our intention to recuperate the theory of sphere sovereignty as a coherent and robust theory of the State. To do that, we will look back, at the origins of sphere sovereignty and its basic tenets. After, we will also look forward, building a different approach to new legal scenarios, especially in international law.

\section{Looking Back: The Origins of Sphere Sovereignty's Theory of the State}

\subsection{Saint Augustine and John Calvin}

The remote source of sphere sovereignty as a theory of the State is found in Saint Augustine, the Bishop of Hippo. Augustine developed a conception of natural law based primarily in his understanding that God is sovereign above all the kings of the earth [1]. In his City of God, Augustine's masterpiece, formulates the 'two kingdoms doctrine'. According to such a theory, the divine law originated in God, is superior to the temporal law, which is subjected to the transcendent moral principle instituted by the divine law [2].

This thought implicates that, if human laws are not subjected to God, then, civil authorities that disrespected the Sovereign's supreme moral standards would be nothing more than great robbers [3]. As Constance Lee puts it, Augustine's doctrine manifests that ' $[t]$ he temporal or civil law found in the earthly kingdom enjoys authority only insofar as it is consistent to the divine will' [2]. 
Augustine's focus on the divine law being equally applicable to all humanity had a significant impact on reformed theologian John Calvin, and it helped him shape his political theology. Calvin agreed with Augustine that a critical feature in human life is the dependence of the sovereignty of God and His providence. God, he affirmed, is the only supreme authority over all humans [4]. Nevertheless, he believed that the Sovereign God did not create the world without earthly authorities [5]. Instead, according to Calvin's teachings, God delegated His sovereign powers to humankind so that civil rulers could govern over people [6]. 'The characteristic of a true [earthly] sovereign is, to acknowledge that, in the administration of his kingdom, he is a minister of God', said Calvin, reinforcing his beliefs in Augustine's teachings [4]. Indeed, Calvin honored the idea of droit divin in which the '[h]ighest authority in monarchy or democracy reigns Dei gratia' [7]:

'The Lord, therefore, is the King of kings. [...] We are subject to the men who rule over us, but subject only in the Lord. If they command anything against Him let us not pay the least regard to it, nor be moved by all the dignity which they possess as magistrates - a dignity to which no injury is done when it is subordinated to the special and truly supreme power of God [4].'

Calvin's formulation on the sovereignty of God influenced several other political thinkers. Martin Bucer, for example, suggested that God ultimately chose civil rulers, who could be deposed if regarded as tyrants [6]. People such as John Knox, George Buchanan, François Hotman and Theodore Beza also supported this doctrine, as they provided a rich framework for the right of resistance against an oppressor State based on God's sovereign powers over the king [6].

Despite his conviction regarding the source of sovereignty, which, as stated above, derived from Augustine's 'two kingdoms doctrine', Calvin's political theology focused on what he called human depravity (a parallel of the doctrine to which Augustine called libido dominandi). [3] This was the assessment of the human condition that Calvin found when studying the Holy Scriptures [4]. He believed it justified the why earthly authorities must submit themselves to a higher, constant and atemporal instance of authority [8]:

'Calvin's firm belief in the corrupt nature of human beings explains his demands for limits to be placed on the civil government, requiring that all laws flowing from it are to be subject to a higher morality. On this view, the existence of a transcendent moral norm is necessary to protect individuals from an ever-present tyranny [2].'

Human depravity culminates in the need for constant public control over the civil magistrates. Not only human laws are subjected to the divine law, according to Calvin, human nature demands people controlling the civil authorities who rule over them [9]. Tyranny is thus the result of uncontrolled power that arises when earthly rulers 'betray the liberty of the people, of which they know that they have been appointed protectors by the ordination of God' [4].

The framers of the United States Constitution of 1787 reproduced this idea that human nature invokes the necessity of control over the government. In Federalist Papers No. 51, the author [10] questions 'what is government itself, but the greatest of all reflections on human nature?' His answer directly refers to the language used by John Calvin, when the author affirms that if men were angels, no government would be necessary. If angels were to govern men, neither external nor internal controls on government would be necessary. In framing a government which is to be administered by men over men, the great difficulty lies in this: you must first enable the government to control the governed; and in the next place oblige it to control itself'. [11] As Alexis de Tocqueville assessed in his celebrated Democracy in America, '[t]here is no power on earth so worthy of honor in itself, or clothed with rights so sacred, that I would admit its uncontrolled and all-predominant authority' [12]. It is because of the understanding of human fallibility that many attribute to John Calvin the germination of current constitutional liberties [13].

\subsection{Johannes Althusius}

Johannes Althusius was a reformed theologian just as Calvin, and he formulated a political theory where the formation of associations and their interactions with each other would constitute a commonwealth [14]. His idea of an association of associations generating a political society is the seed of a federal principle nowadays implemented in many Western societies [15]. To Althusius, politics is the symbiotic process (consociandi) in which individuals gather through different social groups, [14] forming a "network of biblical covenants' [16].

He bases his thought on Calvin's human depravity to state that each association has its own authority, but these authorities are nothing more than mere representative power [17]. Althusius introduces a concept of sovereignty in which an '[a]bsolute power, or what is called the plenitude of power, cannot be given to the supreme magistrate. For first, he who employs a plenitude of power breaks through the restraints by which human society has been contained' [17]. In other words, earthly authorities, Althusius believed, are ontologically inadequate repositories of ultimate sovereignty.

Althusius, in synthesis, delineates a divisible concept of sovereignty in which the transcendent law was administered to earthly authorities. Such authorities, in their turn, should always observe the divine ordinances. The authorities in different associations, together, in the process of consociandi, form what he called a commonwealth [14]. In the Christian political tradition, hence, since its origins in the 'two kingdoms doctrine', there is a division between being an authority and being invested in authority [18].

Another important feature of Althusius work is that he identified the multiple life associations by dividing them into two major groups: public and private. For the interactions between spheres to happen, it is vital to acknowledge that private associations are independent structures, that is, they are not mere parts of the whole political community [19]. 'Politics', for Althusius, 'is the normative duty of promoting social interaction in respect to the internal structure of each 
association' [19].

\subsection{Guillaume Groen Van Prinsterer}

Guillaume Groen van Prinsterer, a scholar influenced by Althusius' teachings, adapted his predecessor's political theory to develop his reasoning concerning the separation of the Church and the State [20]. Although Groen van Prinsterer did not understand society through a pluralist perspective, he appreciated the relevance of separation between public and private spheres, just as Althusius (and his intellectual master, Friedrich Julius Stahl) did [20]. For him, the Church and the State, and some other spheres of life were to be seen as distinct associations. Each should have their own rules according to their respective competencies, and 'the State should not interfere with the internal life of other societal spheres' [20]. As a result, Groen van Prinsterer stated that each of life's associations were to be considered 'sovereign in their own spheres' (souvereiniteit in eigeen sfeer) [21].

It was only when Groen's follower Abraham Kuyper arose in the anti-revolutionary political agenda that the current idea of sphere sovereignty became widely known. His famous opening speech in the inauguration of the Free University of Amsterdam demonstrated the relevance of a social pluralist perspective in the building of the whole of society [22].

\subsection{Abraham Kuyper}

Abraham Kuyper used the same expression coined by van Prinsterer to nominate his theory but applied it to every aspect of human life. In his perspective, not only sphere sovereignty should be used to shield the Church from arbitrary interferences of the State, but also all social and political interactions were to be protected from unduly external interferences [22]. He thus developed the idea of sphere sovereignty in which every sphere that forms a society should be sovereign in its own domain [23].

Kuyper's theory undoubtedly builds upon Augustine's understanding of the absolute sovereignty of God, Calvin's notion of human fallibility, and Althusius' notion of covenantal associations:

'[...] all authority and power in the earth is not inherent, but imposed; so that by nature there can no claim to authority be entered in either by prince or people. God Almighty himself alone is sovereign. In comparison with himself, $\mathrm{He}$ esteems every creature as nothing, whether born in the royal palace or in the beggar's hut. Authority of one creature over another arises, first of all, from the fact that God confers it, not to abandon it himself, but to allow it to be used for his honor [23].'

As Kuyper affirms, therefore, the transcendent moral standard in the divine law is transmitted to humankind through the vesting of authorities who govern over smaller spheres of equal power [22]. As he puts it, 'an earthly Sovereign possess[es] the power to compel obedience only in a limited circle; a circle bordered by other circles in which is another Sovereign', for there are several spheres 'each of which obeys its own law of life, and each subject to its own head' [22]. The pluralist perspective of social existence in Kuyper is a rebirth of Althusius' association's covenantal principle.

According to this concept, societal spheres that continually interact with each other form the human society. The associations in Kuyper's pluralism are equal in authority, and social life is shared without any hierarchy between them.

The notion of shared sovereignty raises many questions, mostly because 'sovereignty' is a concept that has long been contested by different scholars [24]. That is why Kuyper's theory is also known as differentiated responsibility, for it gives to each particular sphere a different function. Distinct spheres have different competencies necessary for the development of their primary functions [25].

\subsection{Herman Dooyeweerd}

Despite its innovative character, Abraham Kuyper's sphere sovereignty soon started to be challenged, for he did not set out a philosophical framework that would explain the underlying implications of his theory [26]. It thus became Herman Dooyeweerd's task to make sphere sovereignty reach a systematic philosophical theory [27].

When it comes to the understanding of sphere sovereignty, Dooyeweerd is responsible for defining the core functions of each sphere (what he called 'leading roles' or 'geno-types'). He identified each orbit's internal structures by investigating the fundamental modal functions that they have [27].

The key point in understanding his theory is to realize that each modality functions as a particular law that defines the structural coherence of a sphere [25]. Dooyeweerd's philosophical theory affirms that each sphere has its own set of rules that relate directly to its modal functions. They are the sole representatives of a particular aspect of human life [20].

The affirmation above is of fundamental relevance to comprehending Dooyeweerd's philosophy. In simple terms, he implies that no societal sphere can have the same radical geno-type as another. In order to maintain such a structural coherence, each sphere has in its intrinsic nature a particular set of laws. Thus, 'an original sphere of authority and competence' must derive their sovereign powers not from another sphere 'but directly from the sovereign authority of God' [20]. Just as '[a]uthority over men cannot arise from men', [23] authority over a sphere cannot arise from within another sphere. To sphere sovereignty, since every sphere has unique rules, it is not possible for a society to have two completely identical spheres of life.

Although a sphere functions in several temporal modalities in life, the geno-type of such an entity is composed of mainly two functions, defined by specific modalities. The formative or foundation function is the fundamental modality for which without it the sphere would not exist, while the leading or qualifying functions guides how each sphere must function [27]. A particular sphere, therefore, will be uniquely defined by both its founding and qualifying functions.

Particularly to the public law features of sphere sovereignty, Dooyeweerd teaches that the State is a 
historically founded public legal community that maintains the monopoly of the 'power of the sword' within a defined territory, so that its core modality relates to the historical and juridical aspects of life [28]. No other sphere of social conviviality can have the exact same founding and qualifying modals as this.

For Dooyeweerd, social life will always allow multiple interactions (what he called enkapsis) between the different societal spheres [28]. However, such interactions do not destroy the leading roles of each sphere. In other words, all spheres have limits and, despite being possible for such boundaries to touch each other in constant interaction, one sphere will not encroach on the other. Indeed, '[o]ne of his basic concerns in developing a theory of the state was to limit the state's power' [29].

What Dooyeweerd affirms, further, is that such an interlacement between spheres could only be qualified as an enkaptic relation if it was the result of 'an interwovenness of individuality-structures' and not an expression of the relation of a whole and its parts [27]. Specifically, Dooyeweerd establishes a difference between an enkapsis and a partwhole relation. The differentiation point between spheres' enkapsis and decentralized organ's relations are the modalities or the geno-types that the sphere has. Once the leading roles of each sphere are uniquely qualified and qualifying, one can see a distinction between a part-whole relationship, or autonomy, and a whole-whole relationship:

'[A]utonomy is not identical with internal spheresovereignty of the different types of societal relationships. The fundamental difference between the two is that autonomy only occurs in the relation of a whole to its parts, whereas a sphere-sovereignty pertains to the relation between social structures of a different radical or geno-type, which in principle lacks the character of a part-whole relation [27].'

As Dooyeweerd addresses it, '[a] genuine enkaptic structural interlacement, taken in our sense, pre-supposes that the structures of things and events, or those of societal relationships functioning in it, have an independent internal leading function and an internal structural principle of their own' [27].

What Dooyeweerd does through this analysis is to recognize a fundamental mistake in Kuyper's theory. Despite acknowledging that Kuyper was the first to grasp sphere sovereignty as a creational principle [20], he observed that the Dutch theologian and politician's description of societal spheres ignored the difference between the leading function and the internal structural principle, as well as the one between public and private associations [20]. Hence, in correcting Kuyper's mistake, and by establishing the need for both formative and qualifying modal aspects for each sphere, Dooyeweerd produced a theoretical framework able to explain the structure of a pluralist society.

In brief, then, sphere sovereignty advocates that the societal spheres cannot be reduced to one single aspect of reality, for, in principle, they are seen in a cosmonomic perspective (with more than one modality as defining its individuality). The spheres are radically (radix) distinct one of the other in their internal structural principle, for this determines the typical functions (formative and qualifying) of a sphere [30]. Sphere sovereignty teaches that while all spheres are subjected to all modal aspects of reality [31], only the primary modal aspects will consist of the true genotype of a sphere.

Thus, according to sphere sovereignty, different associations have constant interaction in enkaptic interwovenness. Such associations must also be treated equally insofar as they have distinct core modalities. The same formative and qualifying functions in distinct associations, however, will evince the existence of a mere decentralization within a single societal sphere (a part-whole relationship). In synthesis, and as a repercussion of this theory, sphere sovereignty will never provide the State with a theoretical framework compliant with its intent of usurping other spheres of their fundamental competencies and functions.

In Dooyeweerd, after long years of development and evolution, the apex of the sphere sovereignty theory of the State is found. The State, therefore, in such a perspective, is a public community with coercive power to execute public justice, equally sovereign as the many other societal spheres. The formative and qualifying functions of the State are definitive to the particular and specific rules of its own sphere.

\section{Looking Forward: The Future of Sphere Sovereignty's Theory of the State}

Although sphere sovereignty's first direct implication occurs to the notion of internal sovereignty, the theory is also of relevance for the analysis of some practical issues in current law. As Johan Van Der Vyver expressed, '[t]he doctrine of sphere sovereignty [...] constitutes a remarkable exception to the absence of originality in present-day expositions of the concept of sovereignty' [26].

Even though 'sovereignty' is a highly contested concept, its main idea is expressed in an international law context. It concerns to either the State's authority in its jurisdiction or to the interactions of a State in an international and globalized world [32]. The first is usually denominated internal or territorial sovereignty, while the second corresponds to external sovereignty or independence [33].

Historically, sphere sovereignty has majorly explained the issues concerning the limits and nature of the State in its internal or territorial facet. In its core, the theory addresses questions related to the boundaries of a territorially defined State, which implicates the idea of a pluralist society. Sphere sovereignty is not put into jeopardy when thought in an international law perspective, albeit that is where there are fluid boundaries to the State, and where social, political and legal limits are increasingly becoming borderless. Although Dooyeweerd and Kuyper did not expressly refer to an international law scenario, their theory implies that even in a 
globalized environment, the State will maintain its primary function and keep its God-delegated authority over people in a determined territory.

The application of Kuyper and Dooyeweerd's theory to an international law environment could indeed affirm that it is not only possible for different associations between States to exist, but, more importantly, that it is viable for international institutions to have delegated authority to exercise specific functions that belong to the States.

To look forward at the future implications of this theory, evince that some of the current international law challenges could be explained by sphere sovereignty: First, the maintenance of State's external sovereignty in a globalized environment; and, second, the justification for the participation of several non-governmental entities in an international realm.

\subsection{Global Law and the Sovereignty of the State-Sphere}

Some argue that the new forms of international interactions require the concept of sovereignty to be left behind [34]. The fact is, however, that there is an urgent need for a more appropriate understanding of States' sovereignty in a globalized world. Despite some opposing voices [35], the States are still to be considered sovereign in their own territory, and the external expression of such sovereign powers is the independence from undesired alien influences [33].

In a sphere sovereignty perspective, even when States become parties to international treaties, or even when they surrender some of their competencies to supranational bodies, they should still be seen as recipients of sovereign authority within their sphere. A justification to such a perspective resides in the ability of States to interact with each other at an international level:

'The rules of law binding upon States therefore emanate from their own free will as expressed in conventions or by usages generally accepted as expressing principles of law and established in order to regulate the relations between these co-existing independent communities or with a view to the achievement of common aims. Restrictions upon the independence of States cannot therefore be presumed [32].'

States, when observed internally in their territory, are undoubtedly sovereign in their own sphere. State's decisions, actions and policies are binding within their orbit of power, and in so far as they are exercising their primary function as dictated by their geno-type, no other sphere can interfere in it. The same situation happens when it comes to an analysis of the State's actions in external or international relations. The State-sphere is not affected solely by international law interactions. It is rather confirmed by it. When an independent State acts in an international arena, it is exercising its God-given sovereign authority to make decisions and administer the 'public justice' outside of its territorial boundaries, but still in compliance with their qualifying functions [36]. The mere geographical perspective should not deteriorate the intrinsic functions of a sphere.

If territorial sovereignty is the cornerstone for the equality of States in an international environment [37], when the State is a part of treaties and conventions, it maintains its sovereignty. Although the State is now acting on a different level, that is, not within its geographical jurisdiction, there is still a structural coherence that finds its source in the internal rules of the State-sphere.

Sphere sovereignty, if applied to an international law environment, would suggest that even in a shared stage with other equally sovereign States, there is still a need to comprehend the existence of an independent sovereign Statesphere that maintains its leading role of being a public community within a territory that exercises coercive power and executes public justice.

\subsection{The Possibility of Non-Governmental Associations to Participate in an International Law Environment}

Just as the State is internally sovereign in its own sphere, which reflects in its capability of being an actor of international law, other societal associations have equally received the ability to exercise authority over a limited circle of life. Thus the same principle follows when other spheres are observed from an external perspective. The participation of non-governmental associations in a globalized law system could be explained, according to sphere sovereignty, in the same way as the State's legal capacity of becoming an international law actor.

If God has given authority to non-governmental associations as sovereign spheres, each one has the power to impede external interferences from any other orbits. It is implied, therefore, that they could also actively participate in all activities related to the fulfillment of their leading roles, independently of the locus of such events.

There are not necessarily absolute territorial borders to associations in the exercise of their competences. Although some societal spheres are limited by what Dooyeweerd called 'spacial' modality, many of the private associations are geographically boundless. This feature allows them to act in different territories. Thus, a non-governmental association, sovereign in its own sphere, can dialogue with, for instance, corporations or even the State-sphere in order to promote a better communal experience for the people subjected to it.

Interactions between non-governmental entities should not be considered inadequate when analyzed through the lenses of sphere sovereignty from an international law perspective. If such associations are sovereign in their own spheres, they are able to make contracts, bind each other by treaties and mutually submit themselves to other equally sovereign societal spheres, according to their core functions and in the limits of their own competencies.

Furthermore, it is possible for associations to be active members of international organizations independently of the States, for they are equally sovereign to exercise authority in their own spheres. For such a scenario to be implemented in an international law environment, a legal personality would be required. Nonetheless, States and other associations (with legitimate legal personality approved by the international law requirements) should be seen as equals even in an 
international law environment, in accordance with their respective competencies.

Non-governmental associations, by sphere sovereignty, could be regarded as sovereign spheres, independently of their geographical boundaries (if in compliance with their geno-types and modal functions). This is a straightforward consequence that is accomplished via a horizontal-oriented view of a pluralist society with roots in the theory of sphere sovereignty.

\section{Conclusion}

Sphere sovereignty teaches that the sovereign powers belong to God alone, even though $\mathrm{He}$ delegates it to be exercised by different associations (societal spheres). Each of these spheres has its own leading role so that none could indistinctly interfere in the other. However, it does not mean that they cannot interact. The interlacement of spheres may be regarded as an enkaptic relation, while a part-whole relation refers to an administrative decentralization of the sphere into autonomous organs.

This philosophical framework of sphere sovereignty signalizes a step towards solving some of the issues that are under discussion in international law. For instance, it shows that different non-State associations can be a part of international relations regardless of the authorization of the State. It also reaffirms the sovereignty of the States in their own territories even when they are interacting with each other in an international environment.

In conclusion, by looking back, it is possible to understand the origins and the basics of such a relevant theory of the State. To look forward, nonetheless, is to apply its tenets into a new conception of the State. Specifically, it helps us to provide a theoretical framework applicable to current international law dilemmas. As shown, some issues that seem to put the State's sovereignty in jeopardy can be solved with a different approach to the contested concept of sovereignty. Sphere sovereignty, therefore, has a tangible relevance to a current international law environment.

\section{Acknowledgements}

I particularly wish to thank Anthony Cassimatis and Nicholas Aroney from the University of Queensland for commenting on earlier drafts that were crucial for the development of this article.

\section{References}

[1] Revelations 1: 5 and Ephesians 1:21-22.

[2] Constance Youngwon Lee, 'Calvinist Natural Law and Constitutionalism' (2014) 39 Australian Journal of Legal Philosophy, 9.

[3] Saint Augustine, The City of God (Cambridge University, 1998), Book III.
[4] John Calvin, The Institutes of the Christian Religion (Christian Classics Ethereal Library, first published in 1536, translated version by Henry Beveridge, 1845), 1238.

[5] David T Koyzis, Political visions and illusions: A Survey and Christian Critique of Contemporary Ideologies (InterVarsity, $2^{\text {nd }}$ ed, 2019).

[6] David W Hall, Calvin in the Public Square: liberal democracies, rights and civil liberties (P\&R, $1^{\text {st }}$ ed, 2009).

[7] Abraham Kuyper, Calvinism: The origin and the safeguard of our constitutional liberties (Bibliotheca Sacra, 1895) 658.

[8] William F Keesecker, The Law in John Calvin's Ethics in Calvin and Christian Ethics (Peter De Klerk (ed), Calvin Study Society, 1987), 19-20.

[9] Augusto Zimmermann, 'The Christian Foundations of the Rule of Law in the West: A Legacy of Liberty and Resistance against Tyranny' (2005) 19 (2) Journal of Creation.

[10] It remains uncertain whether Alexander Hamilton or James Madison is the author of the Federalist Paper No. 51, for all original publishing was subscribed by anonymous 'Publius'.

[11] Alexander Hamilton or James Madison, 'Federalist No. 51' in Clinton Rossiter (ed), The Federalist Papers (New American Library, 1961).

[12] Alexis de Tocqueville, 'Unlimited Power of the Majority in the United States, and its Consequences' in Democracy in America (Henry Reeve (trans.), 1835), Vol I, chapter XV.

[13] Hans Baron, 'Calvinist Republicanism and its Historical Roots' (1939) 8 Church History 30, 39; Kuyper, above n 9, 659; Zimmermann, above n 17; Lee, above n 2, 33, 40.

[14] Johannes Althusius, Politica methodice digesta (Liberty Fund, 1995)

[15] Daniel Elazar, Covenant and Civil Society: the constitutional matrix of modern democracy (Transaction Publishers, 1998), 20; and, Nicholas Aroney, 'Althusius At The Antipodes: The Politica And Australian Federalism' (2003) in Frederick Carney, Heinz Schilling and Dieter Wyduckel (eds), Jurisprudenz, Politische Theorie und Politische Theologie (Duncker \& Humblot, 2004).

[16] Daniel Elazar, "Althusius' Grand Design for a Federal Commonwealth" in Johannes Althusius, Politica methodice digesta (Liberty Fund, 1995) xxxv.

[17] William Dunning, A History of Political Theories from Luther to Montesquieu (Macmillan, 1905) 61-62.

[18] Joan Lockwood O'Donovan, 'Political Authority and European Community: The Challenge of the Christian Political Tradition' (2009) 47 Scottish Journal of Theology 12.

[19] Leonardo Ramos and Lucas G Freire, 'Introdução' ['Introduction'] in Herman Dooyeweerd, Estado e soberania: ensaios sobre cristianismo e política ['State and Sovereignty: Essays on Christianity and Politics'] (Vida Nova, $1^{\text {st }}$ ed, 2014).

[20] Herman Dooyeweerd, Roots of Western Culture: pagan, secular, and Christian options (Paideia Press, 2012).

[21] Guillaume Groen Van Prinsterer, Le Parti Anti-Revolutionaire et Confessionel dans l'Église Réformée des Pays-Bas ( $\mathrm{H}$ Höveker, 1860). 
[22] Abraham Kuyper, Sphere Sovereignty (Speech at the inauguration of the Free University, Amsterdam, 08 March 1880).

[23] Abraham Kuyper, Lectures on Calvinism (Cosimo Classics, originally published in 1931, 2009).

[24] Dieter Grimm, Sovereignty: The Origin and Future of a Political and Legal Concept (Columbia University, $1^{\text {st }}$ ed, 2015).

[25] Gregory Baus, 'Dooyeweerd's Societal Sphere Sovereignty: A Theory of Differentiated Responsibility' (2006) 7 Griffin's View on International and Comparative Law 209-217.

[26] Johan Van Der Vyver, 'Sovereignty and Human Rights' (1991) 5 Emory International Law Review 346.

[27] Herman Dooyeweerd, A New Critique of Theoretical Thought (The Presbyterian and Reformed Publishing, 1969), Part III.

[28] Herman Dooyeweerd, 'The Relation of the Individual and Community from a Legal Philosophical Perspective' (1997) in Alan Cameron \& D F M Strauss (eds) Essays in Legal, Social, and Political Philosophy, (Te Edwind Mellen, 1997) 97.

[29] Roger Townshend, 'Beyond Freedom vs. Democracy: A Dooyeweerdian Contribution to the Individual-Colective Debate' (1991) University of Toronto 20
[30] Herman Dooyeweerd, The Christian Idea of the State (Craig Press, John Kraay (trans), 1968).

[31] Dooyeweerd listed at least 15 modal aspects: Quantitative, Spacial, Kinematic, Physical, Biotic/Organic, Sensitive/Psychic, Analytical, Formative, Lingual, Social, Economic, Aesthetic, Juridical, Ethical/Attitudinal, Pistic/Faith

[32] SS Lotus Case (France v Turkey) (1927) PCIJ (ser A) No 10.

[33] Island of Palmas Case (United States v Netherlands) (Award) (1928) II RIAA 829, ICGJ 392 (PCA).

[34] Robert Jennings, 'Sovereignty and International Law' in Gerard Kreijen (ed), State, Sovereignty, and International Governance (Oxford University, 2002).

[35] For an analysis of the debate on the future of State sovereignty: Alfred Van Staden and Hans Vollaard, 'The Erosion of the State Sovereignty: Towards a Post-territorial world?' in Gerard Kreijen (ed), State, Sovereignty, and International Governance (Oxford University, 2002).

[36] James W Skillen, 'Problems of Theory in Political Integration: Europe' (1976) 40 (1/2) Philosophia Reformata 154-156.

[37] Jurisdictional Immunities of the State (Germany v Italy: Greece intervening) (Judgement) (2012) ICGJ 434, No 143. 